two procumbent teeth rest upon a pad or projecting palate which rises from the inner base of the upper incisors, and whose surface is nearly upon the level of the edges of the upper teeth themselves; the lower incisors, therefore, are only brought into contact with the upper incisors by protruding the jaw forward.

I have, moreover, examined many specimens of the Macropus major, or kangaroo, and of varieties of the Halmaturus known as wallabies and pademelons, when they have been mortally wounded and under the infuence of the spasmodic muscular contractions which occur at the point of death, and $I$ have re peatedly found that they will alternately open the two incisors to their full extent, and unite them again with the energy which characterises all the muscular movements of an animal in its death-strugsle.

If a small object, for instance the blade of a knife, is inserted between the teeth when fully extended, the animal will immediately grasp it with its incisors, which he will do without closing the jaw, showing that the movement is not absolutely dependent upon the action of closing the jaws, although, as I have said above, I believe it usually accompanies it.

The Phalangists or Australian opossums closely resemble the macropidæe in their dental formation, but they possess partially-developed canines in the upper jaw, whilst the latter have none in either jaw except in very early life; but although these opossums have their two procumbent incisors similarly situated, they probably do not possess the power of utilising them in the same manner; I have examined some specimens, but have failed so far to find more than the looseness of connection at the symphysis referred to by Prof. Owen.

In the genus which is represented by the Phascolarctos or native bear of Australia, which possesses the same lower incisors but distinct canines in the upper jaw, this arrangement is certainly wanting, as the rami of the lower jaw are firmly united.

This remarkable formation of the lower jaw of these kangaroos and wallabies is possibly an interesting instance of the retention of a construction, and of a set of muscles in a class of animals which have constantly required their aid to sustain life, which in other families of the animal kingdom have become rigid by ossification and cartilaginous formations, and by atrophy of the muscles in consequence of disuse.

The great plains and deserts over which these marsupials wander in search of food afford an exceedingly precarious supply of pasture in consequence of droughts and bushfires, which not unfrequently follow a superabundance of herbage. These animals, by means of their procumbent teeth which they make use of as shears, are thus enabled to cut off any green shoots or half-buried remains spared by a scorching sun, and obtain nourishment where any grass-feeding placental would certainly starve.

It is in consequence, I believe, of the power which is by this means given to these marsupials of eating scanty pasturage closer to the ground than any other animal, that in the great pastoral districts of New South Wales and Queensland it has been found that they are far more destructive of food than any stock that can be put upon the land, and in places where wallabies and pademelons are exceedingly numerous, it is noticeable that the native grasses in the particular localities which they frequent become completely destroyed, and that such places remain ungrassed until fresh seed is scattered over them by the winds. HENRY WELD BLUNDELL

Gordon Downs, Queensland, December 5, I 878

\section{Measuring the Velocity of Sound in Air}

THE following simple way of arriving at the velocity of sound in air occurred to me lately :- Standing on a straight staircase between two blank walls (brick, and papered), which I find to be $3^{2} \frac{1}{2}$ inches apart, I clap my hands. The effect from each clap is a brief musical sound, metallic in character, and of quite appreciable pitch. It arises, doubtless, from the disturbance travelling to and fro between the walls. The pitch $\bar{I}$ find to be, as nearly as possible, G sharp (in the fourth space). "Now, the number of complete vibrations per second, corresponding to this note, seems to" be about 205 (see Deschanel's "Natural Philosophy," p. 820). This implies that the disturbance, when I clapped my hands, made 4 IO excursions across the space per second. Consequently, $410 \times 32 \frac{1}{2}=13,325$ inches $=1$, rod feet. This is exactly the number Deschanel gives as the velocity of sound in air at $50^{\circ}$ (approximately our mean annina temperature).

\section{Snow Flakes}

WHILST walking home on March 26, about one in the morning, snow began to fall very gently; but instead of the usual powdery or feathery appearance, each flake consisted of a distinct plate, in some cases perfect six-pointed crystals: I I mea. sured some of them, and the largest were as much as five-eighths of an inch across. On taking up a handful the appearance was still more remarkable; instead of the white opaque body one usually sees, the mass was pearly and semi-transparent, and so strongly resembling boracic acid, that I should have had some difficulty in distinguishing a handful of each substance by sight alone.

Near the lamps the effect was very beautiful, more especially when the road became covered, luminous points appearing in all directions, which scintillated like stars as one walked along, whilst many of the falling crystals refiected iridescent butes ô nearing the gromnd.

When out of the town I ignited a piece of hesgnesinm wire, and the effect was most brilliant.

It was a cold, dull night, barometer falling.

Burton-on-Trent

FRANK E.:LOTT.

Rats and Water Casks

IN I 840 , in a voyage from Sydney, viâ Madras, to Eondon, about three weeks after leaving the latter, it was found that i number of water-butts, on their heads in the between-deckes, were leaking. On examining them we ascertained that as thany as ten or twelve butts had been perforated by rats three or four were entirely empty from the leakage so caused, while the retmainder contained ullages from about half to a few gallons. In every case the stave had been eaten through just above the chime hoop, and those which had been apparently most recently operated on had only been perforated so as to cause a slight weeping, while the empty ones showed an opening as large as an ordinary vent-peg hole. The rest of the voyage $a$ tub placed in the square of the main hatchway was kept constantly supplied with water, besides one or more square tins of water on the main deck.

In the above voyage we stayed a week in Madras, and in loosing the foretop-gallant-sail on leaving, a rat and five or six young ones fell to the deck; and the sail was found to be so much eaten and full of holes, made to form and line the nest, that the sail had to be unbent and replaced.
Gurnet Bay, March 31
E. J. A'Court Smith

P.S.-The ship was the Cornziall, East Indiaman, Capt. Cow

\section{HEINRICH WILHELM DOVE}

PROF. HEINRICH WILHELM DOVE was born at Liegnitz, Silesia, on October 6, 1803, and at the age of eighteen passed from the schools of that town to the Universities of Breslau and Berlin, where for the next three years he devoted himself assidiously to the study of mathematics and physics. In 1826 he took his degree of Doctor of Philosophy, his thesis on the occasion being an inquiry regarding barometric changes; and it is further significant of his future life-work that his first published memoir was a paper on certain meteotological inquiries relative to winds, these two subjects holding a first place in the great problem of weather-changes:

Dove began his public life as tutor and Professor at Königsberg, where he remained till 1829 , being then invited to Berlin as supplementary Professor of. Physics. His strikingly clear-sighted, bold, and original intellect turned instinctively to that intricate group of questions in the domain of physics which comptise the science of meteorology, and his success in these fields as an original explorer was so marked and rapid that he soon achieved for himself a seat in the Royal Academy of Sciences, and some time thereafter was ràised to the distinguished position of the Chair of Physics in the University of Berlin.

Among the scientific and fashionable circles or berun he took-first rank as a lecturer, the combined qualities of accurate science, fine imagination, lucidity of style, com- 
manding presence, and the extent over which his utterances were heard, marking him out as the Arago and Brewster of Germany. Germany showered on him in profusion those honours and offices which it gracefully and gratefully bestows on learning and science; and perhaps there is no learned or scientific society of any note that has not the name of Dove enrolled among its honorary members. After a protracted and hopeless illness he died on Sunday last, April 6, in the seventysixth year of his age.

In the Royal Society's Catalogue of scientific papers, the lists under Dove specify 234 memoirs written between the years $1827-73$. These show him to have been a successful worker and investigator in electricity, optics, cry'stallography, and in such practical matters as measures and the art of measuring, or the metric system of civilised nations. But it was to meteorological inquiries he devoted his full strength and all the powers of his mind, and, by his herculean but well-directed labours he has written his name in large imperishable characters on the recurds of science.

His fame rests on the successful inquiries he carried out with a view to the discovery of the laws regulating atmospheric phenomena which apparently are under no law whatever. The work he will be long best known by is his isothermals and isabnormals of temperature for the gloie, in which work one cannot sufficiently admire the breadth of view which sustained and animated him as an explorer during the long toilsome years spent in its preparation. Equally characterised by breadth of view, and what really seemed a love for the drudgery of detail even to profuseness when such drudgery appeared necessary or desirable in attaining his object, are his various works on winds, the manner of their veering and their relations to atmospheric pressure, temperature, humidity, and rainfall, and the important bearings of the results on the climatologies of the globe ; on storms and their connections with the general circulation of the atmosphere; the influence of the variations of temperature on the development of plants; and the cold weatber of May-to which may be added the valuable system of meteorological observations he gradually organised for Germany, and the nany full discussions of these which he published from year to year.

Ii is no small praise to pass on his work to say that tho ie views he propounded, which subsequent researches are likely to modify materially, are those he arrived at by methods of investigation necessarily defective at the time. Thus, for instance, in inquiring into the law of storms, it was not in his power to work from isobaric charts, seeings that the errors of the barometer and their hei ghts above the sea were known in but few cases. When we consider the condition in which he found man's knowledge of weather and the large accessions and developments it received from his hand, the breadth of his views on all matters connected with the science and the welldirected patience, rising into high genius, with which his meteorological researches were pursued, there can be only one opinion, that these give Dove claims, which no other meteorologist can compete with, to be styled "the Father of Meteorology."

THE INSTITUTION OF NAVAL ARCHITECTS $\mathrm{THE}$ twentieth session of the Institution of Naval Architects has now been brought to a close. The meeting, with Lord Hampton in the chair, was held at the house of the Society of Arts, John Street, Adelphi, and was well attended throughout. One of the latest developments in ship-building is shown in the paper on "The Structural Arrangements and Proportions of H.M.S. Iris," by W. H. White, Assistant-Constructor of the Navy. The construction of the Iris marks a new era in the British Navy, being the first vessel built wholly of steel; she is an unarmoured dispatch vessel, specially designed for high speed and great coal endurance. Her principal dimensions are: length between perpendiculars, 300 feet, breadth, extreme, 46 feet, mean load draught, I9 feet 9 inches, displacement, 3,735 tons.

Special attention has been paid to resistance to torpedo attack by constructing the hold in twenty-one separate compartments and the double bottom and bunkers in forty; with the additional weight thus introduced, it is still found that there is a saving of weight in the hull by the use throughout of steel amounting to 12 per cent., or 175 tons. The engines take 28 per cent of the displacement, and 20 per cent. is available for coal, which is estimated to be sufficient for steaming 7,000 knots at a speed of 10 knots per hour. The speed attained by the Iris on the measured mile was $18.6 \mathrm{knots}$, with an expenditure of 2.3 indicated horse-power per ton of displacement as compared with 14 indicated horse-power, required by a torpedo vessel.

In striking contrast with the Iris we have the monster proposed by Rear-Admiral J. H. Selwyn in his paper "On the most Powerful Ironclad." The author of the paper has long advocated some modification of the circular ironclad first proposed by Mr. Elder some years ago, and carried out with some alterations by Admiral Popoff. The vessel here proposed is 370 feet in length 220 feet in breadth, with a draught forward of 18 feet and aft 13 feet. Her armament is to consist of twenty 80 ton guns, or eight 100-ton and eight 80-ton; these are to be mounted in two gun-pits on the Moncrieft hydro-pneumatic principle. The guns are carried on a turn-table of the full size of each gun-pit, the floors of which are composed of steel bars set on edge to provide for ventilation, but to keep out shell fragments; the breast-work round each will consist of 30 inches of armour-plating. The guns would be raised by hydraulic power to fire over the breast-work, recoiling aut omatically under cover for re-loading. The vessel would be protected with a belt of 30 -inch armour round the water-line, and a thickness of 25 feet of coals stowed inside it. There would be two Perkins hydraulic engines of $2 x, 000$ horsepower for propulsion and steering, and these would be at once available for keeping the vescel afloat in case of a leak. The author estimates that if a hole 10 feet square were made by a torpedo, the engines would be able to keep the water under, while danger of sinking by such damage is much lessened, if the engines are partially disabled, by the large number of water-tight compartments. It cannot be denied that the Russian Popoffkas have been far from successful, especially in facility of steerage, which was one of the main advantages claimed for them, but it can only be determined by an actual experiment whether our naval autborities can overcome the difficulties in speed and steering which have baffled the Russian Admiralty. Even if a vessel as here proposed could not be made sea-going, or to attain a 16 -knots speed as claimed, she would at least be more valuable as a harbour defence than a Spithead or Plymouth breakwater fort, and could be adapted to some sites at a less cost in proportion to the weight of armament.

"Armour for ships" by Mr. Barnaby, C.B, Director of Naval Construction, consists of a general review of the progress of armour-plating from its introduction in 1854 down to the present time. The description of the steel turret-plates manufactured by Messrs. Schneider at Creuzot, 32 inches thick, and weighing 65 tons, is not without significance in the present state of depression in the iron trade of this country, but some consolation is to be obtained from the account given of the steel-faced plates of Messrs. Brown and Cammell which shows that some progress is still being made nearer home. The paper by Admiral Sir R. Spencer Robinson, K.C.B., 